\title{
«Que faire des dossiers médicaux après remise ou fermeture du cabinet médical?»
}

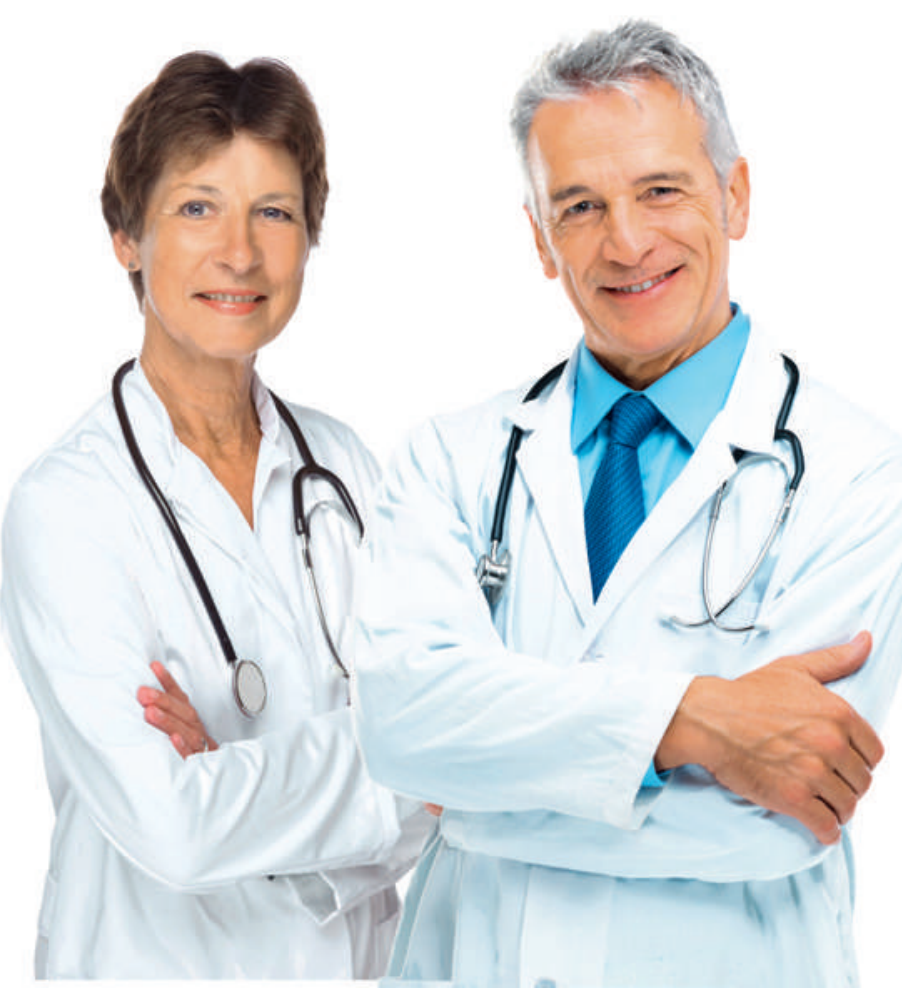

\section{La solution: DMarchives-suisse}

En collaboration avec FMH Services, DMarchîves-suisse vous offre une nouvelle solution facile et garantissant la protection des données pour l'archivage des dossiers médicaux bouclés.

\section{DMarchives-suisse}

Bernstrasse 23

3122 Kehrsatz

Tél. 0319601070

info[at]kgarchiv.ch www.kgarchiv.ch
Martin Sauerer est votre interlocuteur de confiance:

Tél. 0319601070 martin.sauerer[at]kgarchiv.ch

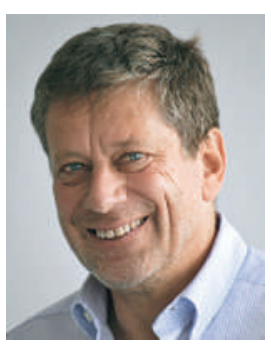

